UDC 336.77:336.201.2-047.44

JEL: M49, G21

\section{Inna Khomenko}

Doctor of Economic Sciences, Associate professor, Professor of the Department of Theoretical and Applied Economics, Chernihiv National University of Technology, Chernihiv, Ukraine

E-mail: innakhomenko28@gmail.com orcid.org/0000-0002-0839-4636

\section{Iryna Sadchykova}

$\mathrm{PhD}$ in Economics, Associate Professor, Associate Professor ot the Department of Financial and

Economic Security

Chernihiv National University of

Technology,

Chernihiv, Ukraine

E-mail: aspirant_chstu@ukr.net orcid.org/0000-0001-5144-1306

\section{Yuliia Krasnianska}

Chernihiv National University of

Technology,

Chernihiv, Ukraine

E-mail: krasnyanskaya.yulia@gmail.com orcid.org/0000-0003-3463-6325

Received: December, 2018

Accepted: February, 2019

DOI: $10.31520 / 2616-7107 / 2019.3 .1-5$

(C) Economics. Ecology. Socium, 2019 CC BY-NC 4.0 license

\section{CURRENT APPROACHES TO THE ANALYSIS OF THE BORROWERS' CREDITWORTHINESS: UKRAINIAN AND WORLD EXPERIENCE}

Introduction. Non-repayment of loans by borrowers not only jeopardizes the profitability of banking structures, but also the ability to calculate them under liabilities - deposit and borrowed funds. This situation is dangerous for the entire banking sector of the country, as it raises a number of acute problems: imbalance of loan and deposit portfolio by volumes and terms; distrust of the population to commercial banks, financial destabilization in the state as a whole, and others like that.

Aim and tasks. The main purpose of this work is to study modern domestic and foreign approaches to assessing the creditworthiness of borrowers.

Results. Based on the analysis of the definitions it is expedient to use the following interpretation of the term "creditworthiness": the financial, economic and legal capacity of the borrower to obtain a loan and return it to the commercial bank in accordance with the terms and conditions of the agreement. At the initial stages of the methodologies developing for the analysis of borrowers' lending, the leading role was played by the coefficient method, which by its nature is considered the simplest and is currently used as an express evaluation and preceded by other research. Currently, almost all commercial banks use a rating approach to assess the borrower's creditworthiness. Such methods also include calculation of coefficients, but contain a predictive component. The rating approach is valuable, because it requires a constant collection of updated information. Often, banks when building credit ratings use the methods of the relevant agencies. It is now believed that the formation of credit ratings allows you to get the most general idea of the borrower's creditworthiness (at the level of the commercial bank) and about the quality of the loan portfolio (at the level of the banking system of the state). Moreover, when assessing the creditworthiness of borrowers - individuals, the rating approach is most often used.

Conclusions. The conducted studies indicate that improving approaches to assessing the creditworthiness of borrowers by commercial banks is particularly relevant for Ukraine. It is important to carry out measures (including administrative) in order to increase the reliability of the input information of borrowers, training of specialized specialists experts, assessment of qualitative data on the debtor, formation of constantly updated statistical databases, adjustment of methodological developments taking into consideration the variability of the economic situation in Ukraine, ensuring transparency of the analysis, etc.

Keywords: crediting of the enterprises, financial analysis, evaluation the creditworthiness of the borrower, indexes of the financial state, financial coefficients, quality indexes of solvency. 
УДК 336.77:336.201.2-047.44

JEL: M49, G21

\section{Інна Хоменко}

Доктор економічних наук, доцент, професор кафедри теоретичної та прикладної економіки, Чернігівський національний технологічний університет, м. Чернігів, Україна

E-mail: innakhomenko28@gmail.com orcid.org/0000-0002-0839-4636

\section{Ірина Садчикова}

Кандидат економічний наук, доцент, доцент кафедри фінансовоекономічної безпеки, Чернігівський національний технологічний університет, м. Чернігів, Україна E-mail: aspirant chstu@ukr.net orcid.org/0000-0001-5144-1306

\section{Юлія Краснянська}

Чернігівський національний технологічний університет, м. Чернігів, Україна E-mail: krasnyanskaya.yulia@gmail.com orcid.org/0000-0003-3463-6325

Отримано: Грудень, 2018

Прийнято: Лютий, 2019

DOI: $10.31520 / 2616-7107 / 2019.3 .1-5$

(C) Економіка. Екологія. Соціум, 2019 CC BY-NC 4.0 ліцензія

\section{СУЧАСНІ ПІДХОДИ ДО АНАЛІЗУ КРЕДИТОСПРОМОЖНОСТІ ПОЗИЧАЛЬНИКІВ: УКРАЇНСЬКИЙ ТА СВІТОВИЙ ДОСВІД}

Вступ. Неповернення кредитів позичальниками не лише ставить під загрозу отримання прибутку банківськими структурами, а й здатність їх розрахунку за зобов'язаннями депозитними та запозиченими коштами. Така ситуація $\epsilon$ небезпечною для всього банківського сектору країни, оскільки породжує ряд гострих проблем: незбалансованість кредитнодепозитного портфеля за обсягами та строками, недовіра населення до комерційних банків, фінансова дестабілізація в державі в цілому тощо.

Мета і завдання. Головною метою дослідження $\epsilon$ сучасних вітчизняних та зарубіжних підходів оцінки кредитоспроможності позичальників.

Результати. На основі проведеного аналізу дефініцій доцільним $є$ використання наступного трактування «кредитоспроможності»: фінансово-економічна та правова спроможність позичальника отримати кредит та повернути його на визначених договором умовах комерційному банку. На початкових етапах розвитку методологій аналізу кредитоспроможності позичальників провідну роль відігравав коефіцієнтний метод, який за своєю сутністю вважається найпростішим i нині використовується як експрес-оцінка та передує іншим дослідженням. Нині практично всі комерційні банки використовують рейтинговий підхід для оцінки кредитоспроможності позичальника. Такі методики також передбачають розрахунок коефіцієнтів, проте містять прогностичну складову. Рейтинговий підхід є вартісним, адже потребує постійного збору оновленої інформації. Часто банки при побудові кредитних рейтингів користуються методиками відповідних агентств. Вважається, що формування кредитних рейтингів дає змогу отримати найбільш загальне уявлення про кредитоспроможність позичальника (на рівні комерційного банку) та про якість кредитного портфеля (на рівні банківської системи держави). Причому при оцінці кредитоспроможності позичальників - фізичних осіб найчастіше використовуються саме рейтинговий підхід.

Висновки. Проведені дослідження свідчать, що удосконалення підходів оцінки кредитоспроможності позичальників комерційними банками є особливо актуальним для України. Важливим є проведення заходів (в тому числі адміністративного характеру) щодо підвищення надійності вхідної інформації позичальників, підготовки профільних фахівців - експертів оцінки якісних даних про боржника, формування статистичних постійно поновлюваних баз, коригування методологічних напрацювань 3 врахуванням мінливості економічної ситуації в Україні, забезпечення прозорості аналізу тощо.

Ключові слова: кредитування підприємств, фінансовий аналіз, оцінювання кредитоспроможності позичальника, показники фінансового стану, фінансові коефіцієнти, якісні показники кредитоспроможності. 
Introduction. Effectiveness of the banking system functioning affects the course of macro- and microeconomic processes in the country. Close relationship between banking structures and the real sector of the state's economy is implemented through the credit mechanism. Under conditions of successful credit policy, borrowing resources can give impetus to the intensification of investment activity of business entities, innovative renewal of the national economy, increase purchasing power of the population, etc. Such changes stimulate the formation of a favorable social and economic climate in the country, which has a positive impact on all spheres of activity.

A mandatory condition for optimal functioning of the credit mechanism of the banking system is the timely repayment of borrowed resources in full amount. Only in such a case, there will be a potential for further buildup of the loan portfolio as a source of financial resources for the development of the state's economy. In addition, correspondence of the real duration of the credit turnover to the planned one is one of the most important conditions for the effective operation of the banking system of the country. Under the normal economic situation in the state, credit operations are the main source of income for commercial banks. Instead, non-repayment of loans by borrowers not only jeopardizes the profitability of banking structures, but also the ability to calculate them under liabilities deposit and borrowed funds. This situation is dangerous for the entire banking sector of the country, as it raises a number of acute problems: imbalance of loan and deposit portfolio by volumes and terms; distrust of the population to commercial banks, financial destabilization in the state as a whole, and others like that.

It is necessary to resolve such issues in Ukraine. According to the data of 2017, the share of non-performing loans in the banking system of the state amounted to $54.5 \%$ [1], which is unacceptable for a market- economy country and indicates the critical state of the loan portfolio. In order to avoid crises in banking, an assessment is made of the borrowers' creditworthiness, which serves as the basis for making financial management decisions on the implementation of credit operations by a commercial bank.
The study of domestic and world methodologies for the analysis of borrowers' creditworthiness in order to improve the methods of valuation used in Ukraine is relevant.

Analysis recent research and publications. For a long time, the problem of the formation of perfect approaches to the analysis of the borrowers' creditworthiness assessment attracted the attention of many domestic and foreign scholars. General description of the analysis methods was carried out by Barjaktarović L., Paunović M., Ječmenica D. [2], Amiti, M., McGuire, P., Weinstein, D. [3], Vovchak O., Meda N. [4] and others. Kovalchuk N. [5] and Chaikovsky Ya. [6] studied existing domestic methods in detail. Vasylchak S. [7] and Pasternak A. [8] emphasized the study of foreign experience. Vygovska N. [9] and Manzhos S. [10] were engaged in methods improvement of the analysis of borrower's creditworthiness. A significant contribution to the modernization of approaches to the analysis of borrowers' creditworthiness was made by foreign scientists Schäfer [21], D. Rose P. [24] and others. The existing broad theoretical framework provides an opportunity for a thorough evaluation of existing methodologies in order to improve them.

Aim and tasks. Despite a large number of research on this subject, issues of qualitative analysis of the borrower's creditworthiness remain relevant, as evidenced by a significant proportion of problem loans of the banking system of Ukraine. It is advisable to study the methodology, analyze the advantages and disadvantages of not only domestic but also foreign approaches to assessing the creditworthiness of borrowers in order to adapt foreign experience to Ukrainian realities.

The main purpose of this work is to study modern domestic and foreign approaches to assessing the creditworthiness of borrowers.

Results. Approaches to assessing the borrower's creditworthiness evolved along with the development of the very concept of "creditworthiness". Currently, there is no single definition of the term (Fig. 1); however, the same understanding of its essence is clearly observed. As a rule, the concept of "creditworthiness" includes: 
- compliance of the entity with certain financial and legal requirements for obtaining a loan; - the borrower's potential ability to repay the loan in a timely and complete manner under certain conditions.

Based on the analysis of the definitions it is expedient to use the following interpretation of the term "creditworthiness": the financial, economic and legal capacity of the borrower to obtain a loan and return it to the commercial bank in accordance with the terms and conditions of the agreement.

At the time of Ukraine's accession to the USSR, the issue of studying the creditworthiness of borrowers was not given special attention, which was due to the existence of the planned economy. That is, cash flows were predetermined by the administrative method rather than based on market principles. The problem of creditworthiness arose acutely during the period when Ukraine became a market-economy country. After all, the formation of a competitive national economy, the development of integration interconnections is impossible in the absence of effective lending of entities by the banking sector. From that time, active researches of scientists in this area began, first methods of analysis of borrowers' creditworthiness appeared.

In general, systematizing theoretical developments of domestic and foreign scientists, the analysis of borrowers' creditworthiness can be presented in the following form (Fig. 1). The main component of this mechanism is the second and third stages, which are to assess the specific financial performance of the borrower. The set of indicator coefficients is determined by the methodology, which is the basis for the creditworthiness analysis process.

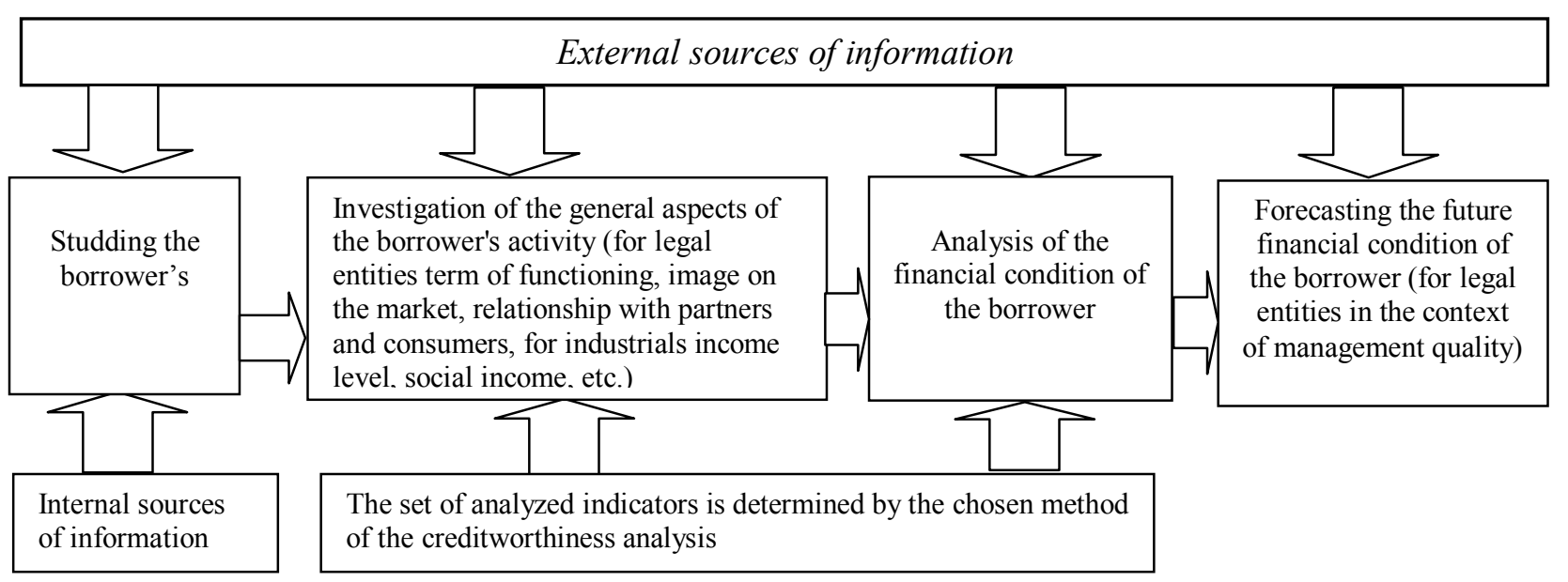

Fig. 1. Basic scheme for assessing the borrower's creditworthiness by a commercial bank Source: Source: compiled by the author.

Currently, there is a large number of approaches to the ways of accessing the be grouped into three groups.

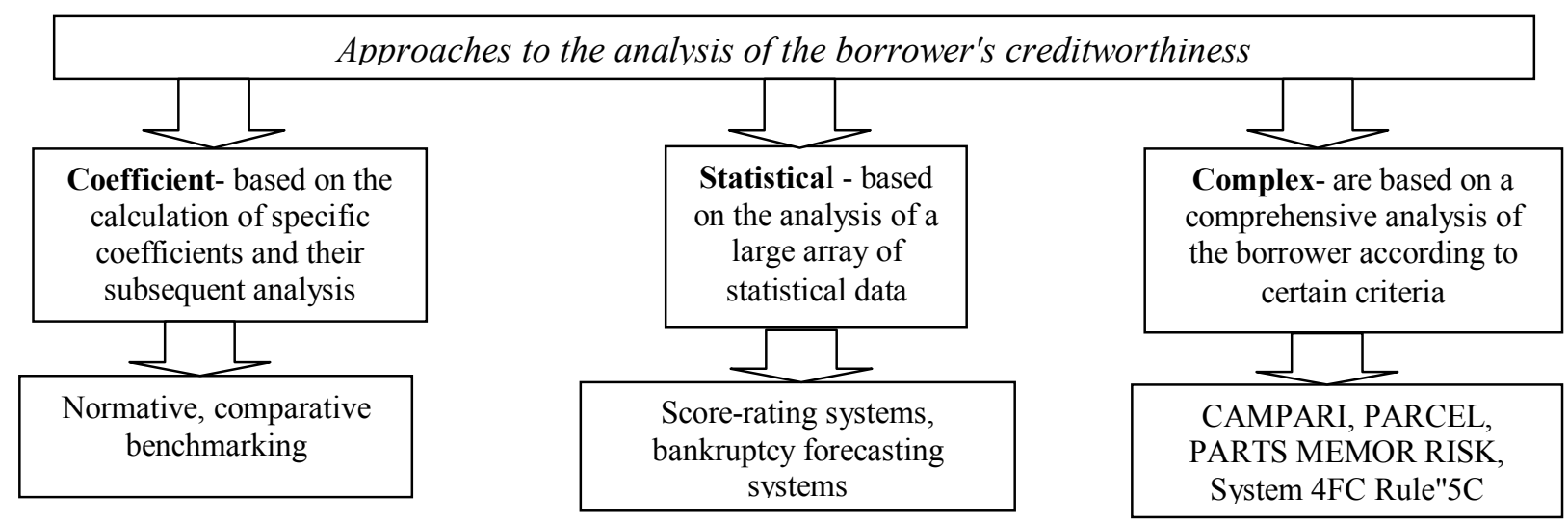

Fig. 2. Approaches to assessing the borrower's creditworthiness by a commercial bank Source: compiled by the author based on [4, 8, 13, 14]. 
At the initial stages of the methodologies developing for the analysis of borrowers' lending, the leading role was played by the coefficient method, which by its nature is considered the simplest and is currently used as an express evaluation and preceded by other research. This approach involves the calculation of relative indicators - coefficients that characterize various aspects of the borrower's activities. For example, for economic entities, as a rule, the indicators of financial stability, liquidity, business activity and profitability are analyzed. The method gives an objective idea of the current state of the enterprise, however, does not take into consideration the dynamics of its development (long-term analytical assessment is not carried out as a result of cumbersome calculations) and does not foresee prediction.

After calculating the coefficients, their further analysis is carried out in the directions: normative analysis (comparison of the results with the norms), comparing (most often the coefficients of this subject with average in the sphere) and benchmarking (analysis of the relative indicators of the investigated enterprise with the most successful competitors). Each of them has certain disadvantages. For example, a conscious "achievement" of the performance indicators of the entity to regulatory values; an occasional renewal of the regulatory framework that results in obsolete data and inadequate research; lack of uniform standards for many coefficients, etc. Conducting a comparison of this approach does not give a real picture of the situation of the company in the market, as it covers the short-term period, and for the domestic economy is characterized by a constant volatility of the situation. For a long period, benchmarking has become popular. Under this approach, credit resources are available to the most reliable borrowers with a consistently high market position. However, the method significantly limited the possibility of obtaining loans for innovative projects of small and medium-sized businesses, the potential for their expansion. This situation led to the use of these areas of analysis in the complex, which partially neutralized the negative aspects of the approach, but made the process cumbersome and prolonged.

Currently, almost all commercial banks use a rating approach (Fig. 3) to assess the borrower's creditworthiness. Such methods also include calculation of coefficients, but contain a predictive component.

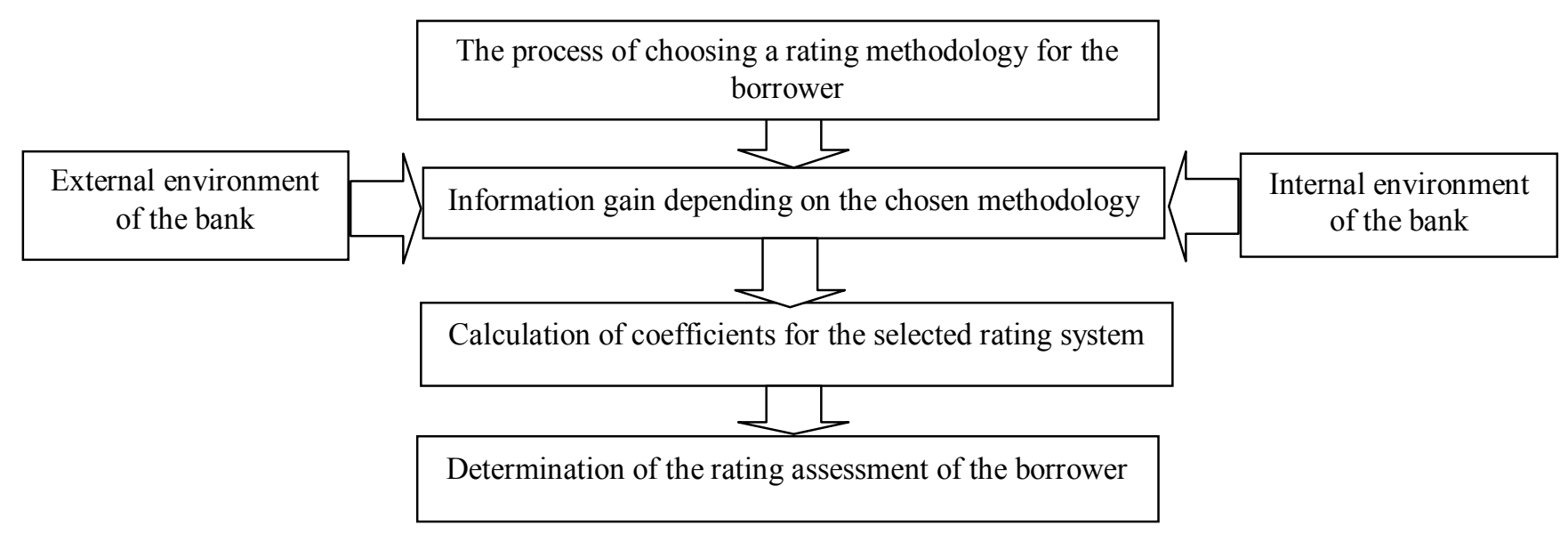

Fig. 3. Mechanism of the rating assessment of the borrower's creditworthiness by a commercial bank

Source: compiled by the author.

The rating approach is valuable, because it requires a constant collection of updated information. Often, banks when building credit ratings use the methods of the relevant agencies (Table 1).

A common practice is the use of qualitative characteristics of their analysis. The methodology of analytical research is, in the main, a commercial secret of such agencies. Of great importance is the assessment of the loan portfolio of the commercial bank directly by the rating agencies, according to the results of which they provide practical recommendations for improving the structure of the credit policy. 


\section{Table 1. Methods for building credit ratings by relevant agencies}

\begin{tabular}{|c|l|}
\hline Rating agency & \multicolumn{1}{c|}{ Essence of the methodology } \\
\hline \multirow{5}{*}{ IBI-Rating } & $\begin{array}{l}\text { The rating is formed on the basis of a detailed analysis of the lending activity of commercial banks. It } \\
\text { is intended to inform potential investors and partners of the bank about the effectiveness of its } \\
\text { lending activities, the presence of problems in the structure of the loan portfolio. It is also used by } \\
\text { commercial bank managers to make managerial decisions about optimizing their lending activity. } \\
\text { The results are executed by the agency using the National Rating Scale separately in terms of long- } \\
\text { term (over 1 year) and short-term (up to 1 year) lending operations. Its formation is carried out on the } \\
\text { basis of the methodology of quality of a loan portfolio developed by the agency. This rating covers a } \\
\text { relatively wide range of subjects of banking activity, as it is included in the mandatory rules of } \\
\text { legislation. Update of rating data is conducted once a quarter or six months. }\end{array}$ \\
\hline \multirow{5}{*}{ NRA "Rurik" } & $\begin{array}{l}\text { The rating takes into consideration a wide range of aspects of commercial banks: direct banking } \\
\text { activities, legal basis of the bank's operation, bank management system and risks, implementation of } \\
\text { economic norms and limits. This technique is developed for all entities that provide credit services. } \\
\text { The ratings received are not publicly interpreted. The main advantage of such a rating is the } \\
\text { adaptation of the methodology to Ukrainian realities, including taking into consideration the } \\
\text { deepening of crisis phenomena. }\end{array}$ \\
\hline Standard- & $\begin{array}{l}\text { The methodology for constructing ratings is based on the use of basic indicators for the CAMELS } \\
\text { model: capital adequacy, asset quality, management peculiarities, profitability, liquidity, share in the } \\
\text { national market. Moreover, the ratings created are long-term, their interpretation to the short-term } \\
\text { period and the comparison of rating scales is possible. }\end{array}$ \\
\hline
\end{tabular}

Source: complied by the author based on [15-17].

It is now believed that the formation of credit ratings allows you to get the most general idea of the borrower's creditworthiness (at the level of the commercial bank) and about the quality of the loan portfolio (at the level of the banking system of the state). Moreover, when assessing the creditworthiness of borrowers - individuals, the rating approach is most often used.

In the NBU Regulation "On Determining the Size of Credit Risk by Banks of Ukraine for Active Banking Transactions", an option for a rating assessment of borrowers' creditworthiness is provided. In practice, this technique is closely linked to another statistical approach - the assessment of the probability of the borrower's bankruptcy. For legal entities, the calculation of an integral indicator of the financial status of the debtor (the approach of forecasting bankruptcy), based on which the borrower is assigned a corresponding class (from 1 to 10), is being ranked. The creditworthiness of the individual borrower is analyzed by quantitative and qualitative parameters (Table 2). The decision to grant a loan to a borrower under this approach is grounded on its affiliation with a particular rating group.

As noted above, statistical models, in addition to rating, include methods of forecasting bankruptcies, the most used of which is discriminatory one. For the analysis of the borrower's creditworthiness under this approach, it is necessary to find the sum of the products of the coefficients that characterize the financial condition of the borrower and the parameters - weight numbers.

Table 2. Classes of the borrower-individual

\begin{tabular}{|c|c|l|}
\hline Class & Name & \multicolumn{1}{c|}{ Brief characteristic } \\
\hline 1 & high & $\begin{array}{l}\text { The repayment amount of the loan principal and interest is not more than 50\% of the net } \\
\text { income of the borrower; payment delay is no more than 7 days; availability of liquid assets; } \\
\text { solvency ratios are above optimal }\end{array}$ \\
\hline 2 & good & $\begin{array}{l}\text { The repayment amount of the loan principal and interest is not more than } 60 \% \text { of the net } \\
\text { income of the borrower; payment delay is 8-30 days; deterioration of the financial status is not } \\
\text { expected; solvency ratios are not lower than optimal ones }\end{array}$ \\
\hline 3 & satisfactory & $\begin{array}{l}\text { The repayment amount of the loan principal and interest is not more than 70\% of the net } \\
\text { income of the borrower; payment delay is 31-60 days; deterioration of the financial status is } \\
\text { expected; some solvency ratios are lower than optimal ones }\end{array}$ \\
\hline 5 & unsatisfactory & $\begin{array}{l}\text { The repayment amount of the loan principal and interest is not more than } 80 \% \text { of the net } \\
\text { income of the borrower; payment delay is 61-90 days; deterioration of the financial status is } \\
\text { expected; solvency ratios are lower than optimal, but not significant }\end{array}$ \\
\hline critical & $\begin{array}{l}\text { The repayment amount of the loan principal and interest is more than 80\% of the net income of } \\
\text { the borrower; payment delay is more than 90 days; solvency ratios are lower than optimal ones }\end{array}$ \\
\hline
\end{tabular}

Source: compiled by the author based on [18, 19]. 
The final (integral index) is subtracted from the obtained value of the free member of the model. This approach is considered highly accurate, but requires the availability of qualitative statistical information. In addition, statistical methods, as a rule, do not involve taking into consideration qualitative characteristics of the borrower, which limits the perception of its real creditworthiness.

The third group of approaches to the analysis of the borrower's creditworthiness include foreign methods. Each of them takes into consideration a well-defined set of indicators (Fig. 4).

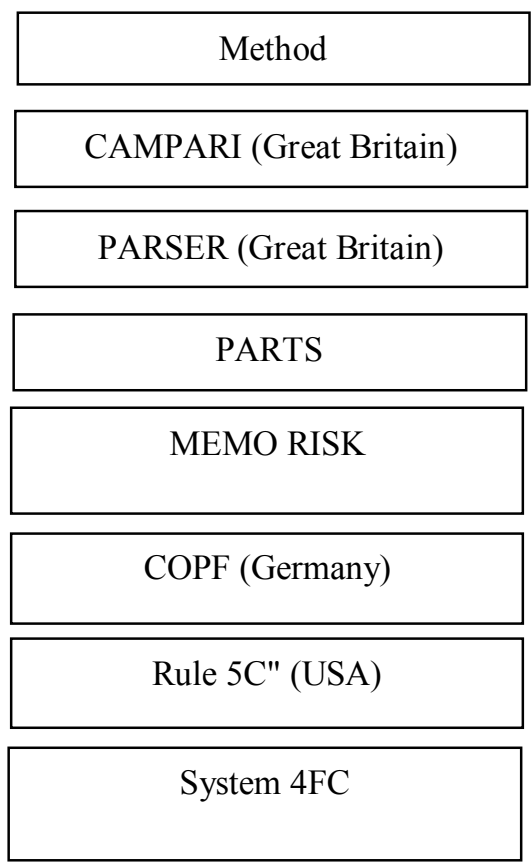

Interpretation of the concept "creditworthiness"

character, ability, marge, pupose, amount, repayment, insurance

person, amount, repayment, security, expediency, remuneration

purpose, amount, repayment, term, security

management, experience, market, operations, repayment, interest, security control

competition, organization, personnel, finance

character, capacity, capital, collateral, conditions

management qUality, undustry dynamics, secunity realization,

financial condition

Fig. 4. Comprehensive methods for building credit ratings by relevant agencies Source: compiled by the author based on [4, 7, 20].

Moreover, the evaluation criteria for this approach include both quantitative and qualitative indicators. Such a comprehensive analysis increases the efficiency of the research of the borrower's creditworthiness. Therefore, its popularity in the developed countries of the world is fully justified. However, an obligatory prerequisite for the successful use of the methodology is highly qualified personnel, because a large number of parameters, especially qualitative, have a subjective component of the study. The higher the knowledge of the expert is, the more accurate the result will be [21-22].

Conclusion. The conducted studies indicate that improving approaches to assessing the creditworthiness of borrowers by commercial banks is particularly relevant for Ukraine. Most of the existing domestic methods are not perfect. From the highlighted approaches used by Ukrainian commercial banks, a combination of the bankruptcy prediction system and the rating model for the analysis of the legal capacity of credit institutions can be considered the most complete. However, its use

in practice is limited to the need for a large incoming array of quality statistical information, which is problematic for Ukrainian realities. Exactly accurate assessment can only be afforded by large banks, which have in their composition a specialized unit, which is a cost item of the bank's expenses. However, even under such conditions, it is virtually impossible to take into consideration the qualitative parameters of the borrower's activities.

Therefore, it is expedient to use foreign experience based on the implementation of integrated methods. It is relevant to conduct further research on this issue in the direction of adapting this approach to Ukrainian conditions. It is important to carry out measures (including administrative) in order to increase the reliability of the input information of borrowers, training of specialized specialists - experts, assessment of qualitative data on the debtor, formation of constantly updated statistical databases, adjustment of methodological developments taking into consideration the variability of the economic situation in Ukraine, ensuring transparency of the analysis, etc. 


\section{REFERENCES}

1. National Bank of Ukraine (2018). Overview of the banking. Retrieved from https://bank.gov.ua.

2. Barjaktarović L., Paunović M., Ječmenica D. (2013). Development of the Banking Sector in CEE Countries - Comparative Analysis. Journal of Central Banking Theory and Practice, 2, 93-114.

3. Amiti, M., McGuire, P., Weinstein, D. (2016). Supply- and Demand-Dide Factors in Global Banking. BIS Working Papers No 639.

4. Vovchak, O. A., \& Meda, N. M. (2013). Modernization of approaches to assessing the creditworthiness of bank borrowers. Bulletin of the National Bank of Ukraine, 12 [in Ukrainian].

5. Kovalchuk, N. O., \& Paskar M. O. (2015). Improving methods for assessing the level of creditworthiness of domestic enterprises. Scientific Bulletin of Kherson State University, 11 (1), 9194 [in Ukrainian].

6. Tchaikovsky, Y. K. (2014). Directions of improvement of the method of analysis of the creditworthiness of the debtor-legal entity. Ukrainian science: past, present, future, 19 (1), 176-188 [in Ukrainian].

7. Vasilchak, S. O., \& Demus, L. M. (2012). Evaluation of the borrower's creditworthiness as one of the methods for ensuring the bank's economic security. Scientific Bulletin of NLTU of Ukraine, 22.1, 154-161 [in Ukrainian].

8. Pasternak, A. L. (2012). Models of analysis of borrower's creditworthiness. Journal of KNUTD, 6, 326-330 [in Ukrainian].

9. Vygovskaya, N. G., \& Vygovsky, V. G. (2017). Development of methodical tools for assessing the creditworthiness of enterprises taking into account off-balance-sheet risks. Bulletin of the ZhDTU, 4 (82), 111-116 [in Ukrainian].

10. Manzhos, S. B. (2013). Problems of assessing the borrower's creditworthiness in the light of sectoral features. Sustainable development of the economy, 4 (21), 351-356.

11. Ghosh, A. (2015). Banking-industry specific and regional economic determinants of nonperforming loans: evidence from US states. J. Financial Stab. 20, 93-104.

12. Galasyuk, V. V. (2001) Assessing the creditworthiness of borrowers: what do we evaluate? Bulletin of the National Bank of Ukraine, 5, 54-56 [in Ukrainian].

13. Bastos, R., \& Pindado, J. (2013). Trade Credit During a Financial Crisis: A Panel Data Analysis. Journal of Business Research, 66(5), 614-620.

14. Nikolaidou, E., \& Vogiazas, S. D. (2013). Credit risk modelling in the romanian banking system: evidence from an ARDL model. In A. Karasavvoglou, P. Polychronidou (Eds.), Contributions to Economics: Balkan and Eastern European Countries in the Midst of the Global Economic Crisis. Springer.

15. IBI-Rating AGENCY (nd). Retrieved from http://ibi.com.ua/uk/.

16. Rurik (nd). NRA. Retrieved from http://rurik.com.ua/rating-principles/methodology.html.

17. Standard Rating (nd). Retrieved from http://standard-rating.biz/rus/products/.

18. Resolution of the Board of the National Bank of Ukraine On Approval of the Regulation on Determining the Size of Credit Risk by Ukrainian Banks for Active Banking Operations No. 351 (2016, June 30). Retrieved from http://zakon2.rada.gov.ua.

19. National Bank of Ukraine (nd). Class of borrower. Retrieved from https://bank.gov.ua/control/uk/publish/article?art_id=123364.

20. Checkley, K. (2010). Lending techniques. Glasgow.

21. Barasinska, N., \& Schäfer, D. (2014). Is crowdfunding different? Evidence on the relation between gender and funding success from a German peer-to-peer lending platform. German Economic Review, 15, 436-452.

22. Rafe, M., \& McKee, K. (2017). Consumer Protection in Digital Credit. Focus Note 108, Washington, D.C.: CGAP.

23. Dietrich, A., \& Wanzenried, G. (2011). Determinants of bank profitability before and during the crisis: Evidence from Switzerland. Journal of International Financial Markets, Institutions and Money, 21(3), 307-327.

24. Rouz P.S. (1995). Bank management, M.: «Delo». 